\title{
Preliminary dendroecological survey on pedunculate oak (Quercus robur L) stands in Tuscany (Italy)
}

\author{
A Santini, A Bottacci, R Gellini * \\ Laboratorio di Botanica Forestale, Dipartimento di Biologia vegetale, Università di Firenze, \\ Piazzale delle Cascine, 28, 50144 Firenze, Italy
}

(Received 22 February 1993; accepted 27 July 1993)

\begin{abstract}
Summary - This paper studies the influence of climate on pedunculate oak radial growth in some stands of central Mediterranean Italy. Three populations growing along the course of the River Arno were selected. Core samples were measured, and their growth curves standardized and modellized, in order to isolate the climate signal. The response functions were calculated by orthogonal regression of the variables of the tree ring (dependent variables) and the climate (explicative variables). This paper provides an eco-physiological analysis of the results. This study helps us understand how the ecotype of the pedunculate oak has adapted to a Mediterranean climate where water supply is a strong limiting factor.
\end{abstract}

dendroecology / pedunculate oak / water supply / Mediterranean forest / eco-physiology

Résumé - Observations dendroécologiques préliminaires sur des peuplements de chênes pédonculés en Toscane (Italie). Le travail concerne l'étude de linfluence du climat sur la croissance radiale du chêne pédonculé dans I'ltalie centrale. On a choisi et échantillonné 3 peuplements le long de l'Arno. Les échantillons ont été mesurés et les courbes d'accroissement ont été standardisées et modélisées dans le but d'isoler le signal climatique. Les fonctions de réponse ont été calculées par régression orthogonalisée entre la variable cerne (variable dépendante) et les variables climatiques (variable explicative). Les résultats sont discutés du point de vue écophysiologique. Cette étude aide à comprendre comment des écotypes de chêne pédonculé se sont adaptés au climat méditerranéen où la disponibilité de l'eau est le facteur limitant le plus important.

dendroécologie / chêne pédonculé / sécheresse / forêt méditerranéenne / écophysiologie

\section{INTRODUCTION}

Pedunculate oak or common English oak (Quercus robur $L$ ) is the most widespread oak in Europe. Its distribution area extends from Scandinavia and Russia to the Mediterranean, from the Atlantic to the Urals and the Caucasus (Gellini, 1985). It is so ecologically flexible that in certain microhabitat conditions it can be found in phyto-

* This paper is dedicated to the memory of Prof R Gellini, Forest Professor at the University of Florence improvisely deceased during the preparation of the paper. 
climatic areas ranging from Lauretum to Picetum.

The fact that this species is represented over such a vast distribution area can be explained by its genetic variability. There exists a wide number of ecological or climatic types, as well as photoperiodic ecotypes, such as the chêne de Juin ( $Q$ peduncolata var tardissima Simonkaii) which, as the French name suggests, starts its vegetative period very late (Gellini, 1985).

It was the existence of such a vast number of ecotypes that prompted our dendroecological study of the pedunculate oak population in Tuscany. The aim of our survey is to typify the Tuscan ecotype.

The genus Quercus, which plays a major role in forestry, is currently being studied by many European researchers working on the phenomenon of oak decline, or dépérissement du chêne (Young, 1965; Petrescu, 1974; Aussenac, 1978; Klepac, 1981; Becker and Levy, 1982; Bernard, 1982; Ragazzi et al, 1986; Oosterban et al, 1990).

In our study we used the methodology proposed by Guiot and coworkers from the Laboratoire de Palynologie and Botanique Historique at the University of Saint Jérôme, Marseilles, and the software package "PPPHALOS" (Guiot, 1990). Accordingly, we calculated the response functions obtained from the orthogonal regression analysis of modellized ring-width and monthly climate variables: total rain- fall; mean maximum and minimum temperatures.

A comparison with data derived from other studies on pedunculate oak in Italy (Nola, 1988; 1991) has not yielded the expected results. The reason for this is primarily that the environments from which the samples came were very different and climate is hardly ever the only growth limiting factor. The whole combination of the stand's ecological characteristics (including microclimate) determines the greater or lesser growth levels (Nola, 1991).

\section{MATERIALS AND METHODS}

We sampled 3 populations growing along the course of the River Arno (table I). The first is in the natural park of San Rossore (Pisa), at the river's mouth, where the trees sampled were located in 3 distinct subsamples. In these areas the soil layer is deep with a sandy texture, and has developed on fluvial sediments that are recent but suitable for highly evolved plant formations; these terrains do not present chemical or physical limitations except for the fact that they are underwater for a large part of the year due to the emergence of the aquifer. The vegetation consist of a mixed uneven-aged wood of broadleaves, including pedunculate oak, narrowleafed ash (Fraxinus angustifolia Vahl), European ash (Fraxinus excelsior $L$ ), smooth-leaved elm (Ulmus minor Mill), white poplar (Populus alba $L$ ) and, sporadically, stone pine (Pinus pinea $L$ ). Pedunculate oak grows on the dominant plane.

The second population is in the Cascine Park in Florence, a former game reserve belonging to

Table I. Environmental characteristics of the sampled populations.

\begin{tabular}{lccrr} 
Population & Annual rainfall $(\mathrm{mm})$ & Medium temperature $\left({ }^{\circ} \mathrm{C}\right)$ & Altitude $(\mathrm{m})$ as/a & Age of trees \\
\hline S Rossore & 938 & 14.9 & 3 & $1810-1989$ \\
Cascine & 856 & 14.7 & 50 & $1822-1989$ \\
Renacci & 875 & 13.8 & 220 & $1750-1989$
\end{tabular}

a asl: at sea level. 
the Grand Dukes of Tuscany; the populations were chosen from the wooded area along the banks of the river. The soil has developed on alluvial terrain created by the Arno river with pebbles and sandy clay; the result is a deep soil layer with the clay component varying according to the original catchment basin. The vegetation consists of a sparse mixed wood, on 2 planes, with a prevalence of broadleaves. Pedunculate oak is represented by isolated individuals on the dominant plane. There is no renewal at all of pedunculate oak.

The third population grows along the Arno in the stretch between Arezzo and Florence, at Renacci. The soil layer has developed from river and lake sediments, stratified with clayey sand, clay and occasional pebbles; the result is a deep terrain, well drained owing to its sand component, and suitable for highly evolved forest formations. The vegetation consists in a mixed un-even-aged wood of broadleaves, with pedunculate oak, pubescent oak (Quercus pubescens Willd), hop hornbeam (Ostrya carpinifolia Scop) and flowering ash (Fraxinus ornus $\mathrm{L}$ ). Pedunculate oak grows prevalently on the dominant plane.

The first 2 populations are part of residual plane-growing forests, whereas the third is in a hilly area.

We sampled dominant or codominant plants: 17 at S Rossore; 10 at Cascine; and 11 at Renacci. Every sampled plant grew in woods except for 2 trees of Renacci population that were isolated. We extracted 2 core samples from each tree, at a height of $1.3 \mathrm{~m}$ from the ground; the samples were taken from opposite sides of the trunk, following the direction of the contour lines on hilly ground, and simply from north to south in flat areas. We used a $60-\mathrm{cm}$ Pressler increment borer, which was long enough to allow us to reach the centre of the tree. Where possible we also took stem disks.

Information concerning the stand and the individual tree was recorded and later included in a specially designed computerized data bank, using a DBASE III Plus program. This enables us to store data on each of the trees sampled and to retrieve the information later according to specific features, for example, data on all the trees of a certain stand, or on all those growing on a certain type of soil, etc. Accurate sampling is particularly useful in guaranteeing a successful survey (Schweingruber, 1983).

\section{Dendrochronological survey}

The measurement of the ring widths was done at the Silviculture Institute at the University of Florence with a CCTRMD (computer-controlled tree-ring measurement device) connected to CATRAS (computer-aided tree-ring analysis system, Aniol, 1983, 1987). With this method yearly increments can be recorded with a resolution of up to $0.01 \mathrm{~mm}$.

Using the crossdating procedure, we then checked the validity of the measurements we obtained.

Statistical tests (correlation coefficient $t(r s)$ (sensu Aniol, 1983) and coincidence coefficient (Corona, 1986) and visual comparisons helped us select the series which offered a correlation with a $t(r s)$ value at least higher than 3 with the other series from the same stand. From these we calculated the mean curve for each stand. The results in S Rossore, the first area, show that the correlations are good or excellent only within the individual substands sampled, while they are very poor $(t(r s)<3)$ between the different substands and for this reason a mean chronology was not constructed. The second area, Cascine Park, has 7 individual series with excellent correlations, in terms of both visual and statistical comparisons; these series were averaged, yielding a mean curve of $168 \mathrm{yr}$. In the third area, Renacci, 8 curves were averaged, yielding a mean curve that goes from 1750 to 1989; unfortunately, only one tree dated back to 1750 , while the others were much younger. Statistical and visual comparisons of the mean curves obtained from these last 2 sampling areas yield encouraging results: statistical comparison show that the 2 curves overlap for $168 \mathrm{yr} ; t(r s)=6.13$; coincidence coefficient $=$ 68.0 (99.9) (fig 1).

\section{Dendroecological survey}

In order to obtain as much information as possible on the behaviour of trees in relation to climate from dendrochronological data, these data must be processed statistically so as to eliminate gradually all information not related to climate. As a result of this procedure, ring-width curves tend to lose their usual shape: they become a representation first of the indices calcu- 


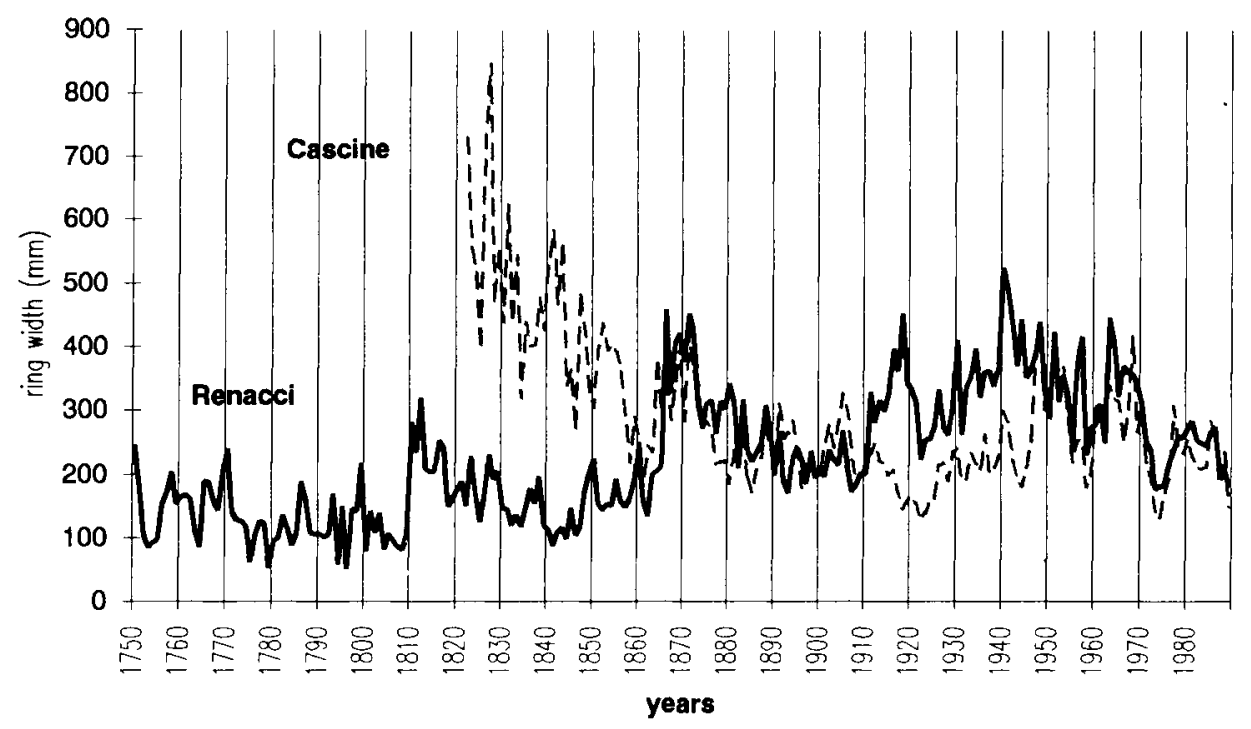

Fig 1. Synchronization of the average curves of ring width from the Cascine and Renacci stands.

lated by a standardization by polynomial curves and, then, of the residues calculated by an autoregressive moving average (ARMA) modellization. Finally, the regression between the time series of the residues and the climatic parameters is calculated. For this method, refer to Tessier (1984), Messaoudene (1989), Guiot (1989; 1990), Brugnoli and Gandolfo (1991), Nola (1991); Santini and Martinelli (1991).

We used the climatic data provided by the University of Pisa (Agrarian Studies Faculty) for the period from 1927 to 1988 in our calculation of the response functions for $S$ Rossore; for the Cascine and Renacci sites we used data provided by the Ximeniano Observatory in Florence, for the period 1879 to 1988.

The climatic parameters we took into consideration were total monthly rainfall $(P)$, mean maximum monthly temperatures and mean minimum monthly temperatures. The monthly parameters used cover the 12-month period between the completion of the ring in year $t-1$ and the completion of the ring in year $t$, that is the period between October of the year before the formation of the ring and September of the year of formation of the ring. It is commonly be- lieved that this is the period over which rings are formed in the northern part of the Mediterranean basin (Tessier, 1984).

The series of yearly growth increases are modellized through an ARMA process (Box and Jenkins, 1970), which applies a yearly growth model to each series. This function expresses the sum of 3 elements in mathematical terms: the climate, which can be expressed as a random function; the trend, meaning the fact that the growth of a particular year can be correlated not only to the climate of that year but also to the growth and climate of the previous years; and cycles, or repetitive elements such as parasite infestations or forest management operations.

One way of decoding the climate signal and distinguishing it from background noise is to use orthogonal regression with the bootstrap procedure (Efron, 1979; Diaconis and Efron, 1983) and an analysis of the principal components of the 24 climate variables considered so as to calculate the relation between the ring-width time series and the climate parameters time series considered. This relationship is called the response function. This procedure was applied using the software package PPPHALOS (Pro- 
grams in Paleoclimatology: Prevision of Hiatus and Analysis of Linkages between Observation and between Series, Guiot, 1990).

Some of the raw tree-ring width series were preliminary indexed with polynomials of different degrees, since the low frequency variance (LFV) caused by long cycles (especially the age of the tree) made it impossible to perform an analysis of the high frequency variance (HFV) caused by the climate.

Every raw tree-ring width series was modellized with an ARMA process in an order which varies according to the series being considered. In calculating the ARMA model to be applied (using GALOTO software, which works by choosing the best model among different trials with the Akaike information criterion (AIC) an autocorrelation of residues at regular intervals was highlighted. This probably indicates that there are periodicities in the tree's growth for periods equal to the order of residue autocorrelation and which have a strong influence on growth. These periodicities can be related to years in which pedunculate oaks had rich or medium rich crops, as De Philippis and Bernetti (1990) also reported, or phytophagous pullulations, as can be observed on the core that sometimes present early wood only.

The response functions were calculated on the variables of the tree ring (dependent variables) and of the climate (explicative variables). The regressors of the explicative variables have been grouped together in order to make the relation more stable (table II). In order to check the stability and significance of the response functions, the bootstrap procedure was used. In this kind of procedure the $n$ observations of the ring values and the corresponding climatic data are drawn at random and returned to the batch.
The pseudo-data set thus established was useful for calibration, and the correlation coefficients were calculated on this set. These coefficients were used to reconstruct the climatic data pertaining to the calibration and verification years. The verification years were those that were not randomly selected. The correlation coefficient was calculated between observed and estimated data, both on calibration and verification years. Then 50 lots were randomly selected and 50 reconstructions were performed. Once the 50 reconstructions have been completed, a mean correlation coefficient $(R)$ between estimated and observed data and its relative standard deviation ( $S$ ) were calculated, both for the calibration and verification years. The $R$ value and the $R / S$ ratio for the verification years give an estimation of the global significance of the response function (Brugnoli and Gandolfo, 1991).

If the $R / S$ ratio is 1.68 , the significance is $90 \%$, if $R / S=2$ it is $95 \%$, if $R / S=2.58$ it is $99 \%$, and if $R / S=3.33$ it is $99.9 \%$; when $R / S$ ratio is greater than 4 the probability of error is less than 0.001 . Each number is either positive or negative depending on whether the correlation is direct or inverse. Figure 2 describes the correlation; the size of the columns is proportional to the significance. Positive regression coefficients indicate a direct relationship. This means that above average monthly climate parameters correspond to above-average growth, whereas if the monthly values are below average then the growth will be below average too. On the other hand, negative coefficients indicate an inverse correlation. This means that above-average monthly parameters correspond to belowaverage growth, and below-average parameters lead to above-average growth (Messaoudene, 1989).

Table II. Statistical features considered for the analysis.

\begin{tabular}{lcccc}
\hline Population & NST ${ }^{\mathrm{a}}$ & NDA ${ }^{\mathrm{b}}$ & ARMA models & Climatic regressors \\
\hline S Rossore & 17 & 10 & 1.1 & 20 \\
Cascine & 10 & 7 & $1.0 ; 1.1 ; 2.1$ & 16 \\
Renacci & 11 & 8 & $1.1 ; 2.0$ & 17 \\
\hline
\end{tabular}

\footnotetext{
a NST: number of sampled trees; ${ }^{D}$ NSA: number of trees used for the dendroecological analysis.
} 


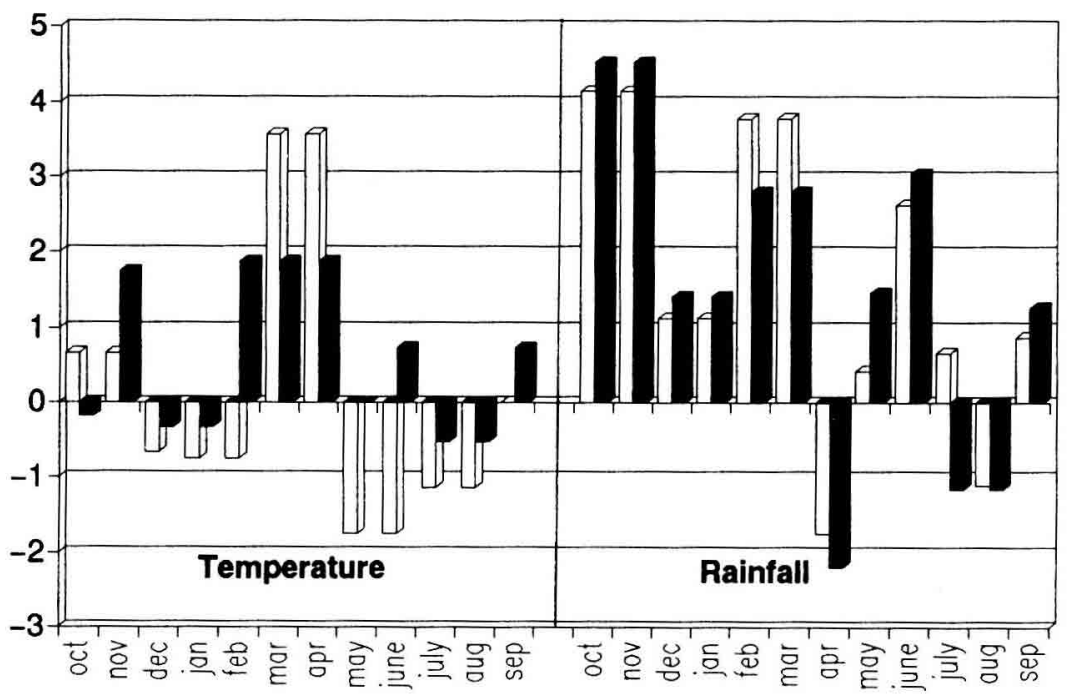

(a)

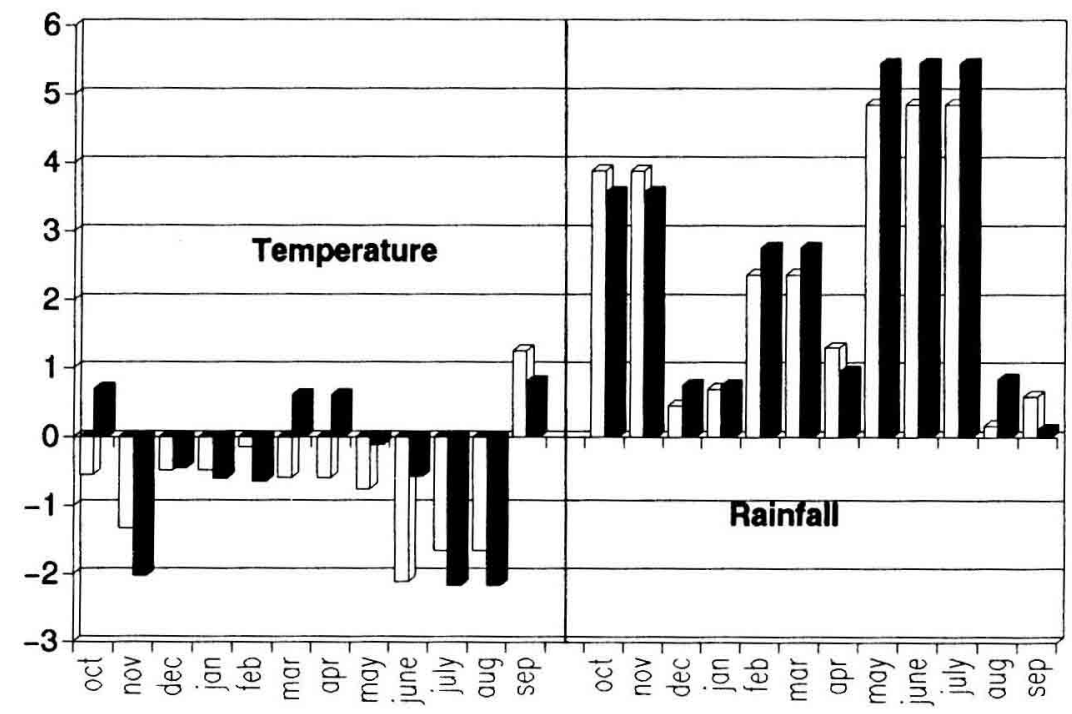

(b)

Fig 2. Diagram showing the response functions in the Cascine stand (a) and Renacci stand (b). The diagram shows the regression between mean minimum temperatures, rainfall and the tree-ring variable together with the regression between mean maximum temperatures, rainfall and the treering variable $[\square$. The regressions refer to the entire 12 -month period. The $x$ axis records the months and the $y$ axis shows the significance, expressed in the coding $(R / S)$ explained in the text. The overall significance of the function is 2.78 in the Cascine stand and 2.63 in Renacci stand for minimum temperature and 2.31 in the Cascine stand and 2.63 in Renacci stand for maximum temperature. 


\section{RESULTS}

\section{Stand 1: S Rossore (Pisa)}

For the series of residues resulting from the ARMA modelling of this sampling area we calculated the response functions using the climate data of Pisa in the years 19271988. In no case did this function yield statistically significant results. Several different groupings of the climate regressors were tried, but none of them ever yielded results that were even barely significant. The regression was also calculated separately for temperature and rainfall, but the result was the same.

Our explanation for this lies in the fact that the pedunculate oaks in S Rossore grow in a habitat characterized by abundant groundwater which, in some seasons, even surfaces, giving the site an almost marshy appearance (the so-called lame). Because of this, the differences in radial growth from one season to another are minimal. In dendrochronology trees that live in this kind of habitat are known as complacent trees (Fritts, 1976); since their growth is only marginally influenced by climate variables, they are not suited to a dendroecological study like this one. If we accept this explanation we can also understand why the crossdating between the different sampling plots was so difficult, as we mentioned earlier. Since the climate variables do not determine the high frequency variance, the oscillations in current increase are relatively low and growth is characterized by microstand factors, which vary from one point in the site to the next. In conclusion, we believe that this is a stand in which pedunculate oaks grow in good conditions, at least as far as water supply is concerned, conditions good enough to compensate for the negative effect of high temperatures on growth.

\section{Stand 2: Cascine (Firenze)}

The results obtained show that (fig 2) trees growing in this area need a constant water supply in the period preceding the formation of the ring, especially in OctoberNovember and February-March. In March-April the trees also need high temperatures, both maximum and minimum, since late frost has a negative effect. In the period of full growth the only evident direct correlation is with rainfall in the month of June. The trees of this stand had a higher growth in summer when the rainfall was abundant in the previous months. There are no correlations with any of the climate regressors in July and August. This means that in these months rainfall does not have any influence on growth.

\section{Stand 3: Renacci (Arezzo)}

In this stand we noticed that trees in the same class of diameter can belong to very different age groups. We found several trees aged 50-60 yr growing very close to one aged $250 \mathrm{yr}$. The response functions were calculated from 1918 onwards and only for the series which began in that year, in order to ensure that it would be possible to calculate and compare the mean value of the functions. To check whether different results are obtained if the period of observation is increased, the reponse functions for the older trees were calculated starting from 1878. Since in these calculations we are considering a longer period, the response functions of 2 more trees reached the threshold of statistical significance. This is the only difference we found. In figure 2 we can see that the most significant correlation for the minimum temperature is the inverse correlation observed in November, July and August; whereas for maximum temperatures, the 
most significant is the inverse correlation in June. This suggests that the inverse correlation with minimum temperatures in the summer months indicates that high night-time temperatures create unfavourable conditions for the growth of pedunculate oaks. The inverse correlation with maximum temperatures in June, when the trees are probably in full meristematic activity, suggests that they need low daytime temperatures.

\section{CONCLUSIONS}

An analysis of the response functions shows, firstly, that there is a greater significance in the response function calculated between the mean minimum temperature and rainfall on the one hand, and radial growth on the other: this could mean that minimum temperatures have a stronger influence on growth. Secondly, rainfall always shows a direct correlation with growth, with the exception of the data for rainfall in April in the Cascine stand. This is due to the marked hygrophilia of the pedunculate oak.

In Mediterranean environments the water supply is the main limiting factor for the pedunculate oak, which explains why it grows only in areas where the ground water can compensate for a shortage of rainfall (Bernetti, 1991). This is indeed the case in $\mathrm{S}$ Rossore, where tree growth shows no statistically significant response to climate regressors. The pedunculate oak's marked hygrophilia has been studied by Becker and Levy (1982, 1983, 1986; Becker et al, 1986). Who demonstrated that it grows well on acid hydromorphous soils where it is practically the only dominant, but who also noted that after a year of exceptional drought this tree suffers a terrible decline, so much so that its very survival is threatened in certain habitats. Damage caused by drought is possible and the degree of the damage is directly correlated with the needs of the species and the age of the tree, especially when the trees have developed in very moist environments and suddenly have to face periods of drought. Furthermore, the pedunculate oak is not equipped with any morphological feature to help it overcome periods of drought, as is the case with other species typical of the Lauretum.

The direct correlation between rainfall in the autumn months and growth recorded during the following year can be attributed to 4 possible causes. The first is that, once growth is completed, the bud forms, and it is therefore of crucial importance that there is a sufficient water supply available at that time. The second explanation could be that rainfall in October, November and December might favour a new growth spurt, leading to the formation of a false tree ring (Maugini, 1949), which, however, we did not find. The third explanation could be that the roots do not respond to the photoperiods governing the evolution of the epigeous part of the tree. With a few exceptions, roots will continue to grow if they have a sufficient supply of nutrients and water, until the soil temperatures become too low (Kozlowski, 1971). As a result, if it rains during this period the roots will grow and when the new growth cycle begins, the following year, the tree will have a much larger root structure and will therefore be in a position to grow more. Lastly, above-average autumn rainfall levels delays phylloptosys which means that the photosynthesis continues; the result is an accumulation of carbohydrates which helps the growth of the following year.

The negative effect of minimum temperatures in November, in the Renacci population, could be explained by the fact that this is the period when the buds are formed, as we said earlier. Their dormancy is induced not only by the short daylight period, but also by the low temperatures. 
The direct correlation with the amount of rainfall in February and March appears to be connected to a physiological requirement. In fact, this direct correlation takes place immediately before the cambium becomes active again, as Maugini (1949) observed in Quercus pubescens Willd and $Q$ ilex and Ciampi (1951) in $Q$ suber L. These authors stressed the fact that the cambium became active again during a period of equinoctial rains, with high temperatures, reaching a maximum of $25^{\circ} \mathrm{C}$ in April (Maugini, 1949).

In order to record above-average growth levels the trees in the Renacci population need an ample supply of water in May, June and July. This is probably due to the fact that the growth pattern of the pedunculate oak is completely predetermined and organized in successive fluxes (Ward, 1964). In fact, within a single growth season the same axis can organize several buds consecutively, and each one of them, when its time comes, will start to grow. Therefore, an ample water supply during this period is essential to ensure that growth can continue.

These data suggest a further hypothesis, which will need to be verified. Since there are still significant correlations between the growth in the current year and the climate parameters for the months of July and August, it is likely that the activity of the cambium does not end in October. It probably continues, although for exactly how much longer is mainly determined by stand and ecological conditions. It would be very interesting to carry out parallel studies on the rhythm of cambium activity, in order to offer a more complete interpretation of the data gathered in the present survey.

\section{ACKNOWLEDGMENTS}

The authors would like to thank the Silviculture Institute of the University of Florence for the use of their dendrochronographer; they would also like to thank N Casini, L Sani and M Ciolli for their assistance during the field surveys and $C$ Gandolfo for her useful editorial suggestions.

\section{REFERENCES}

Aniol RW (1983) Tree-ring analysis using Catras. Dendrochronologia 1, 45-53

Aniol RW (1987) A new device for computerassisted measurement of tree-ring widths. Dendrochronologia 5, 135-141

Aussenac G (1978) La sécheresse de 1976 : influence des déficits hydriques sur la croissance des arbres forestiers. Rev For Fran 30, 103-114

Backer M, Levy G (1982) Le dépérissement du chêne en forêt de Tronçais. Les causes écologiques. Ann Sci For 39, 4, 439-444

Becker M, Levy G (1983) Le dépérissement du chêne. Les causes écologiques. Exemple de la forêt de Tronçais et premières conclusions. Rev For Fran 35, 5, 341-356

Becker M, Levy G (1986) Croissance radiale comparée de chênes adultes (Quercus robur $\mathrm{L}$ and $Q$ petraea (Matt) Liebl) sur sol hydromorphe acide : effet du drainage. Acta Oecol, Oecol plant 7(21), 2, 121-143

Becker M, Levy G, Garreau B (1986) Comportement expérimental de semis de chêne pédonculé, Chêne sessile et hêtre en présence d'une nappe d'eau dans le sol. Ann Sci For 43 (2), 131-146

Bernard C (1982) Contribution à l'étude du dépérissement du chêne en forêt de Tronçais. Intervention des champignons pathogènes des racines. Mémoire de troisième année, INRA Clermont-Ferrand, France. $107 \mathrm{p}$

Bernetti G (1991) Appunti sul genere Quercus in Italia. In: Problematiche fitopatologiche del gen. Quercus in Italia (A Ragazzi, R Tiberi, eds). Firenze 19-20 November 1990, 12-36

Box GPP, Jenkins GM (1970) Time series analysis: forecasting and control. Hoden-Day, San Francisco, USA, $575 \mathrm{p}$

Brugnoli A, Gandolfo C (1991) Analisi dendroclimatiche sull'abete rosso (Picea abies (L) Karst) del Trentino orientale: primi risultati. Monti e Boschi 6, 51-56 
Ciampi C (1951) Evoluzione della cerchia legnosa in Quercus suber L (dall'ottobre 1946 al settembre 1947). NGB/ vol LVIII, 293-304

Corona P (1986) Metodologie dendrocronologiche, Monti e Boschi, XXXVII, 39-44

De Philippis A, Bernetti G (1990) Lezioni di selvicoltura speciale. CUSL Firenze 1991, $239 \mathrm{p}$

Diaconis P, Efron B (1983) Méthodes de calculs statistiques intensifs sur ordinateurs. Pour la Science 46-58

Efron B (1979) Bootstrap methods: another look at the Jacknife. Ann Stat, vol 7, 1-26

Fritts HC (1976) Tree Rings and Climate. Academic press, London, $567 \mathrm{p}$

Gellini R (1985) Botanica forestale. Vol II. CEDAM Padova, $205 p$

Guiot J (1989) Methods of calibration. In: Methods of Dendrochronology: Applications in the Environmental Sciences (E Cook and L Kairiuskstis, eds) Kluwer Academic Publishers and IAASA, Dordrecht, 165-178

Guiot J (1990) Methods and Programs of Statistics for Paleoclimatology and Paleoecology (J Guiot and L Labeyrie, eds) $253 p$

Klepac D (1981) Les forêts de chênes en Slavonie. Rev For Fr 33, 86-104

Kozlowski TT (1973) The Shedding of Plant Parts. Academic Press Inc, New York, $560 p$

Maugini E (1949) L'evoluzione della cerchia legnosa in Quercus pubescens Willd e in Quercus ilex $L$ nel clima di Firenze (dal giugno 1946 al giugno 1947). NGBI, vol LVI, 4, 593611

Messaoudene M (1989) Approche dendroclimatologique et productivité de Quercus afares Pomel et Quercus canariensis Willd dans les massifs forestiers de l'Akfadou et de Beni-
Ghobri en Algérie. Thèse Doctorat en Sciences, Univ Aix-Marseille III

Nola $P$ (1988) Dendrocronologia della quercia nella pianura padana. Dendrochronologia 6 , 179-192

Nola P (1991) Primo approccio alla dendroclimatologia della quercia (Quercus robur $\mathrm{L}$ ) e Quercus petraea (Mattuschka) Liebl) in pianura padana (Italia settentrionale). Dendrochronologia 9, 71-93

Oosterban A, Nabuurs GJ, Maas GJ (1990) Een onderzoek naar verbanden tussen sterfte in zomereikenpstanden in Nederland en de grondwatertrap. In: Rapport Rijkinstituut voor Onderzoek inde Bos landschapsbouw "De Dorschamp" nr 532, Wageningen, $60 \mathrm{p}$

Petrescu M (1974) Les dépérissements du chêne en Roumanie. Eur J For Path 4, 222227

Ragazzi A, Dellavalle Fedi I, D'Onofrio G (1986) Osservazioni preliminari su un deperimento di Quercus robur L, Quercus cerris L e Quercus frainetto Ten in Italia. Atti Giornate Fitopatologiche 2, 241-252

Santini A, Martinelli N (1991) Indagine dendroecologia sull'abete bianco (Abies alba Mill) di Serra San Bruno (CZ). GBI 6, 895-906

Schweingruber FH (1983) Der Jahrring. Verl $P$ Haupt Bern-Stuttgart, Germany, FR $276 p$

Tessier $L$ (1984) Dendroclimatologie et écologie de Pinus silvestris $L$ et Quercus pubescens Willd dans le Sud-Est de la France. Thèse Doctorat d'État, Université Aix-Marseille III

Ward WW (1964) Bud distribution and branching in red oak. Bot Gaz 125, $217 \mathrm{p}$

Young CWT (1965) Death of pedunculate oak and variations in annual increments related to climate. For Comm For Rec 55, 1-15 